\title{
Production of monoclonal antibodies specific to Macrobrachium rosenbergii nodavirus using recombinant capsid protein
}

\author{
Pradit Wangman', Saengchan Senapin ${ }^{2,3}$, Parin Chaivisuthangkura1, \\ Siwaporn Longyant ${ }^{1}$, Sombat Rukpratanporn ${ }^{4}$, Paisarn Sithigorngul ${ }^{1, *}$ \\ ${ }^{1}$ Department of Biology, Faculty of Science, Srinakharinwirot University, Sukhumvit 23, Bangkok 10110, Thailand \\ ${ }^{2}$ CENTEX Shrimp, Faculty of Science, Mahidol University, Bangkok 10400, Thailand \\ ${ }^{3}$ National Center for Genetic Engineering and Biotechnology (BIOTEC) Pathumthani 12120, Thailand \\ ${ }^{4}$ Center of Excellence for Marine Biotechnology at Chulalongkorn University, \\ National Center for Genetic Engineering and Biotechnology (BIOTEC), Bangkok 10330, Thailand
}

\begin{abstract}
The gene encoding the capsid protein of Macrobrachium rosenbergii nodavirus (MrNV) was cloned into pGEX-6P-1 expression vector and then transformed into the Escherichia coli strain BL21. After induction, capsid protein-glutathione-S-transferase (GST-MrNV; $64 \mathrm{kDa})$ was produced. The recombinant protein was separated using SDS-PAGE, excised from the gel, electro-eluted and then used for immunization for monoclonal antibody (MAb) production. Four MAbs specific to the capsid protein were selected and could be used to detect natural $\mathrm{MrNV}$ infections in $M$. rosenbergii by dot blotting, Western blotting and immunohistochemistry without cross-reaction with uninfected shrimp tissues or other common shrimp viruses. The detection sen-

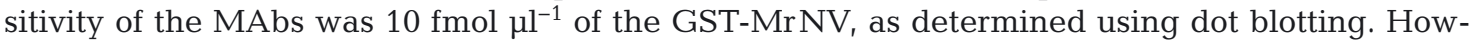
ever, the sensitivity of the MAb on dot blotting with homogenate from naturally infected M. rosenbergii was approximately 200 -fold lower than that of 1-step RT-PCR. Immunohistochemical analysis using these MAbs with infected shrimp tissues demonstrated staining in the muscles, nerve cord, gill, heart, loose connective tissue and inter-tubular tissue of the hepatopancreas. Although the positive reactions occurred in small focal areas, the immunoreactivity was clearly demonstrated. The MAbs targeted different epitopes of the capsid protein and will be used to develop a simple immunoassay strip test for rapid detection of MrNV.
\end{abstract}

KEY WORDS: Capsid protein $\cdot$ Extra small virus $\cdot$ XSV $\cdot$ Immunohistochemistry $\cdot$ Macrobrachium rosenbergii nodavirus $\cdot \mathrm{MrNV} \cdot$ Monoclonal antibody $\cdot$ Western blot

\section{INTRODUCTION}

Outbreaks of disease due to Macrobrachium rosenbergii nodavirus (MrNV) were first reported from hatchery-reared $M$. rosenbergii postlarvae (PL) in the French West Indies (Arcier et al. 1999, Bonami \& Sri Widada 2011) and later in Taiwan (Wang et al. 2008), China (Qian et al. 2003), India (Sahul Hameed et al. 2004), Thailand (Yoganandhan et al. 2006) and Australia (Owens et al. 2009). MrNV infection may cause nearly $100 \%$ mortality of PL in hatcheries and nursery ponds within $5 \mathrm{~d}$ after appearance of the first gross signs of the disease. These signs include whitish appearance of muscle tissue, particularly in the tail portion, leading to the name white tail disease (WTD). 
Genome-based detection methods with high specificity and high sensitivity for detection of MrNV include dot blot hybridization, in situ hybridization (Sri Widada et al. 2003) and 1-step RT-PCR in the form of single tests for MrNV or XSV (Sri Widada et al. 2003, Sahul Hameed et al. 2004) or multiplex tests for both viruses (Yoganandhan et al. 2005, Tripathy et al. 2006, Senapin et al. 2010). A 2-step real-time RT-PCR method (Zhang et al. 2006) and a reverse transcription loop-mediated isothermal amplification (RT-LAMP) method (Pillai et al. 2006, Puthawibool et al. 2010) have also been described. Although a thermal cycler is not required for RT-LAMP, the technique is still expensive and fairly complicated, and a laboratory is required. Therefore, these molecularbased techniques are not useful for pond-side detection by shrimp farmers, who require simpler and quicker disease monitoring and disease-outbreak confirmation methods that are easy to perform with high specificity and optimal sensitivity. These objectives may be achieved using immunoassay methods. Use of a polyclonal antibody (PAb) (Romestand \& Bonami 2003) and monoclonal antibodies (MAbs) (Qian et al. 2006) to detect purified MrNV using sandwich ELISA and Western blotting (Sahul Hameed et al. 2011) have been described. Although the cost per sample of these antibody-based detection methods is much lower than that of genome-based detection methods, these methods still require a well-equipped laboratory.

In the present study, MAbs specific to MrNV were developed by mouse immunization with recombinant capsid protein of MrNV expressed heterologously in Escherichia coli. These MAbs were selected and characterized using various immunological methods including dot blotting, Western blotting and immunohistochemistry. The objective was to obtain MAbs that targeted a variety of MrNV epitopes for use in the development of a simple and rapid strip test that required at least 2 MAbs, one as a captured antibody and another as a labeled antibody, that recognized different epitopes of the antigen in sandwich format (Sithigorngul et al. 2006, 2007, 2011).

\section{MATERIALS AND METHODS}

\section{Sample preparation}

Macrobrachium rosenbergii PL samples infected naturally with MrNV preserved in $70 \%$ ethanol at $4^{\circ} \mathrm{C}$ for $3 \mathrm{~d}$ were obtained from a shrimp hatchery in Chachoengsoa Province, Thailand. The preservative solution was changed to $95 \%$ ethanol before storage at $-70^{\circ} \mathrm{C}$ prior to use. Part of each sample batch was homogenized in PBS (0.15 M phosphate-buffered saline, pH 7.2) at approximately 1:10 (V:V) and centrifuged at $3000 \times g$ for $30 \mathrm{~min}$. The supernatant was aliquoted into small vials and stored at $-70^{\circ} \mathrm{C}$. Another part of each sample batch was fixed in Davidson's fixative and processed for immunohistochemical analysis. Uninfected $M$. rosenbergii PL were also collected and used as negative controls in various assays. Adult $M$. rosenbergii naturally infected with MrNV-were obtained from the local market in Bangkok and also fixed in Davidson's fixative for use in immunohistochemical assays. Nested RTPCR for MrNV and XSV (Senapin et al. 2010) was used to verify the presence of both viruses in the samples.

\section{MrNV RNA preparation}

MrNV-infected Macrobrachium rosenbergii PL were homogenized in lysis buffer $(50 \mathrm{mM}$ Tris- $\mathrm{HCl}$ pH 9, $100 \mathrm{mM}$ EDTA, $50 \mathrm{mM} \mathrm{NaCl}, 2 \% \mathrm{SDS}$ ), and RNA was extracted from $200 \mu \mathrm{l}$ of the homogenate using a High Pure viral nucleic acid kit (Roche Molecular Biochemicals) as described in the product manual. The extracted nucleic acid was stored at $-70^{\circ} \mathrm{C}$.

\section{Cloning and expression of MrNV capsid protein gene}

RNA from MrNV-infected shrimp was reverse transcribed into cDNA using Superscript III reverse transcriptase (Invitrogen) following the manufacturer's directions. Polymerase chain reaction (PCR) was performed to amplify the MrNV capsid protein gene without the corresponding transmembrane region at the N-terminus (nucleotides 91 to 1116 of the open reading frame [ORF] of MrNV capsid protein gene; GenBank accession number NC005095.1), using this cDNA as a template, $P f x$ polymerase (Invitrogen) and the primers MrNVF91 (5'-CG GGA TCC CCG CAG ACG GTT CCC AAC-3') and MrNVR (5'-G GAA TTC CTA ATT ATT GCC GAC GAT AG-3') containing added restriction sites (underlined). The PCR conditions were $94^{\circ} \mathrm{C}$ for $2 \mathrm{~min}$ and 35 cycles of $94^{\circ} \mathrm{C}$ for $15 \mathrm{~s}, 57^{\circ} \mathrm{C}$ for $30 \mathrm{~s}$ and $68^{\circ} \mathrm{C}$ for $1 \mathrm{~min}$, followed by an extension at $68^{\circ} \mathrm{C}$ for $15 \mathrm{~min}$. The $1041 \mathrm{bp}$ PCR product was digested with restriction enzymes BamHI and EcoRI and then cloned into the corresponding restriction sites of the pGEX-6P-1 expres- 
sion vector and transformed into Escherichia coli strain BL21. The integrity of the ORF of the recombinant plasmid was verified using DNA sequencing with 5'pGEX sequencing primer (5'-GGG CTG GCA AGC CAC GTT TGG TG-3'). For comparison, a pGEX-6P-1 expression vector without the inserted gene was also used to concurrently transform the $E$. coli strain BL21 with the MrNV-pGEX-6P-1 plasmid.

\section{Preparation of recombinant MrNV capsid protein}

Escherichia coli transformed with MrNV-pGEX6P-1 was cultured in Luria-Bertani (LB) broth to the exponential phase. Expression of recombinant protein was induced with $1 \mathrm{mM}$ isopropyl- $\beta$-D-thiogalacto-pyranoside for $4 \mathrm{~h}$. After centrifugation at $3000 \times g$ for $20 \mathrm{~min}$ at room temperature, the bacterial pellet was resuspended in a buffer containing $100 \mathrm{mM} \mathrm{NaH}_{2} \mathrm{PO}_{4}, 10 \mathrm{mM}$ Tris-HCl, $8 \mathrm{M}$ urea (pH 8) and $1 \mathrm{mM}$ phenylmethylsulfonyl fluoride and sonicated until a clear lysate was obtained. The lysate was separated using $12 \%$ sodium dodecyl sulfate polyacrylamide gel electrophoresis (SDS-PAGE). After treatment with $0.3 \mathrm{M} \mathrm{KCl}$, the band of recombinant fusion protein called glutathione-S-transferase (GST)-MrNV was excised and collected in dialysis bags. The recombinant protein was eluted with a Transblot apparatus (BioRad) at $70 \mathrm{~V}$ for $6 \mathrm{~h}$ and dialyzed in PBS. The protein concentration was determined using the Bradford assay (Bradford 1976). The recombinant protein solutions were adjusted to $0.4 \mathrm{mg} \mathrm{ml}^{-1}$, divided into $0.5 \mathrm{ml}$ aliquots and stored at $-70^{\circ} \mathrm{C}$.

\section{Immunization}

GST-MrNV protein mixed with complete Freund's adjuvant in a 1:1 ratio was injected intraperitoneally into 4 Swiss mice at $0.02 \mathrm{mg}$ protein per mouse. The mice were subsequently injected with the same protein mixed with incomplete Freund's adjuvant 3 more times at 2 wk intervals. One week after the fourth injection, antiserum from each mouse was collected and tested using Western blotting against expressed lysates of Escherichia coli containing either GST or GSTMrNV proteins or homogenate samples from uninfected and MrNV-infected PL. The mouse that gave the strongest immunoreactivity was subsequently boosted with the same antigen without adjuvant $3 \mathrm{~d}$ before hybridoma production.

\section{Production of monoclonal antibodies}

A cell fusion protocol was adapted from the method developed by Köhler \& Milstein (1976) with modifications described by Mosmann et al. (1979). A P3X myeloma cell line was used as the fusion partner. Fusion products from 1 mouse were plated onto 20 microculture plates (96 wells per plate). The identification of positive cultures was performed by dot blotting against GST and GST-MrNV, by dot blotting and Western blotting against homogenates from MrNVinfected and uninfected PL and by immunohistochemistry, as described below. The selected hybridoma clones were recloned twice using the limiting dilution method to establish cell lines that were stored in liquid nitrogen.

The class and subclass of the mouse immunoglobulins produced by hybridomas were determined using sandwich ELISA with a Mouse MonoAb ID Kit: HRP (Zymed).

\section{Specificity testing \\ Dot blotting}

Lysates of Escherichia coli BL21 containing either the GST, GST-MrNV proteins or homogenate samples from uninfected and MrNV-infected PL were applied to nitrocellulose membranes ( $1 \mu \mathrm{l}$ per spot) that were baked at $60^{\circ} \mathrm{C}$ for $10 \mathrm{~min}$ and then incubated in MAbs in hybridoma-conditioned culture medium from each culture well at a dilution of 1:20 in 1\% blocking solution (1\% nonfat dry milk, $0.1 \%$ Triton X-100 in PBS) for $5 \mathrm{~h}$. After extensive washing in $0.5 \%$ blocking solution, the membrane was incubated in horseradishperoxidase-labeled goat anti-mouse gamma immunoglobulin heavy and light-chain-specific antibody (GAM-HRP; Bio-Rad) at 1:1500 dilution in 1\% blocking solution for $3 \mathrm{~h}$. The membrane was then washed for $5 \mathrm{~min}$ in $0.5 \%$ blocking solution and incubated in substrate mixture containing $0.03 \%$ diaminobenzidine (DAB), $0.006 \%$ hydrogen peroxide and $0.05 \%$ cobalt chloride in PBS (Sithigorngul et al. 2002).

\section{Western blotting}

Lysates of Escherichia coli BL21 containing either the GST or GST-MrNV proteins or homogenate samples from uninfected and MrNV-infected PL were separated using $12 \%$ gel SDS-PAGE according to the method described by Laemmli (1970). The samples 
were electrophoresed for $3 \mathrm{~h}$ at $60 \mathrm{~V}$, and one part of the gel was stained using Coomassie Brilliant Blue R250. For Western blot analysis, the samples resolved using SDS-PAGE were transferred onto nitrocellulose membranes using a Transblot apparatus (BioRad). The nitrocellulose membranes were incubated in $5 \%$ blocking solution for $10 \mathrm{~min}$ and treated with MAbs in culture medium (1:200 dilution) or mouse antiGST-MrNV capsid protein antiserum (1:5000 dilution and preabsorbed with E. coli lysate containing GST) for $5 \mathrm{~h}$. After extensive washing in $0.5 \%$ blocking solution, the membranes were incubated with GAMHRP at 1:1500 dilutions for $3 \mathrm{~h}$. They were then washed extensively as before and incubated in a substrate mixture containing $0.006 \%$ hydrogen peroxide, $0.03 \%$ DAB and $0.05 \%$ cobalt chloride in PBS.

\section{Immunohistochemistry}

Alcohol-preserved PL specimens infected naturally with MrNV were further fixed in Davidson's fixative solution for $24 \mathrm{~h}$ before processing for paraffin sectioning. Serial sections of tissues (8 $\mu \mathrm{m}$ thickness) were prepared and processed for indirect immunoperoxidase staining using MAbs obtained from the present study at a 1:100 dilution and then GAM-HRP at a 1:1000 dilution in 10\% calf serum in PBS for $5 \mathrm{~h}$ at $37^{\circ} \mathrm{C}$ each step. After extensive washing with PBS, peroxidase activity was visualized by incubation with $0.03 \%$ DAB and $0.006 \%$ hydrogen peroxide in PBS for $5 \mathrm{~min}$. The preparations were counterstained with hematoxylin and eosin Y (H\&E Stains), dehydrated in a graded ethanol series, cleared in xylene and mounted in Permount (Sithigorngul et al. 2000). Positive reactions were visualized as brown coloration against pink cytoplasm and purple nuclei. Pieces of tissues dissected from adult Macrobrachium rosenbergii infected naturally with MrNV were also directly fixed in Davidson's fixative solution for $24 \mathrm{~h}$ and processed using the same protocol as the alcohol-preserved PL.

Cross reactivity of the MrNV-specific MAbs to various shrimp viruses was determined using immunohistochemistry. Shrimp samples infected with Penaeus monodon densovirus (PmDNV; also called hepatopancreatic parvovirus), Penaeus monodon nucleopolyhedrovirus (PemoNPV; also called monodon baculovirus), Taura syndrome virus (TSV), white spot syndrome virus (WSSV), yellow head virus (YHV) and infectious myonecrosis virus (IMNV) were processed for paraffin sectioning and immunohistochemistry using MAbs specific to MrNV. The results were compared to those from MAbs specific to PmDNV (Rukpratanporn et al. 2005), TSV (Longyant et al. 2008), WSSV (Chaivisuthangkura et al. 2004), YHV (Sithigorngul et al. 2002), PemoNPV (Boonsanongchokying et al. 2006), Penaeus stylirostris densovirus (PstDNV; Sithigorngul et al. 2009) and IMNV (Kunanopparat et al. 2011).

\section{Sensitivity testing with recombinant MrNV capsid protein}

Purified GST-MrNV protein was serially diluted with PBS, and $1 \mu \mathrm{l}$ of each dilution was spotted onto nitrocellulose membranes and processed for dot blotting using the MrNV-specific MAbs generated in the present study. The last dilution yielding a clear positive result was determined.

\section{Sensitivity comparison between MAbs and 1-step RT-PCR}

The sensitivity of MrNV detection in a shrimp infected naturally was determined using MAbs specific to MrNV. The MrNV-infected shrimp PL homogenate was diluted serially with uninfected shrimp homogenate and processed for dot blotting as described above. The last dilution of shrimp homogenate yielding a clear positive result was determined. RNA from the same PL homogenate was also extracted with a High Pure viral nucleic acid kit (Roche Molecular Biochemicals), serially diluted with uninfected shrimp nucleic acid and tested for MrNV using single step RT-PCR with primers MrNVF91 and MrNVR as described above. The RT-PCR conditions were $50^{\circ} \mathrm{C}$ for $30 \mathrm{~min}, 95^{\circ} \mathrm{C}$ for $5 \mathrm{~min}, 4^{\circ} \mathrm{C}$ for $5 \mathrm{~min}$ and 35 cycles of $95^{\circ} \mathrm{C}$ for $1 \mathrm{~min}, 55^{\circ} \mathrm{C}$ for $45 \mathrm{~s}$ and $72^{\circ} \mathrm{C}$ for $1 \mathrm{~min}$, followed by an extension at $72^{\circ} \mathrm{C}$ for $15 \mathrm{~min}$.

\section{RESULTS}

\section{Capsid protein gene cloning and expression}

The expected PCR amplicon of 1041 bp was obtained for the MrNV capsid protein gene (Fig. 1). Expression of the GST-tagged-MrNV fusion protein (GST-MrNV) was visualized by Coomassie Brilliant Blue staining as a band with the expected molecular mass of $64 \mathrm{kDa}$ (Fig. 2A, Lane 3). After the recombinant band was cut from the gel and eluted, a highly purified fusion protein was obtained (Fig. 2A, Lane 4) and used at $0.4 \mathrm{mg} \mathrm{ml}^{-1}$ protein for immunization. 


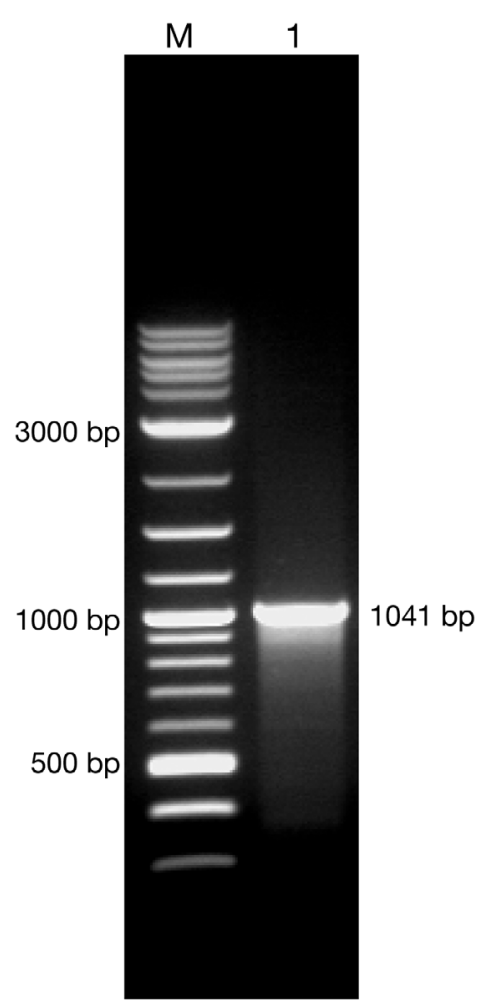

Fig. 1. Ethidium bromide stained gel of the expected MrNV capsid protein gene PCR amplicon of 1041 bp (Lane 1). Lane M: DNA markers

\section{Monoclonal antibody production}

After the fourth immunization, the mouse that produced the strongest immunoreactivity was used for hybridoma production (Fig. 2B). Approximately 1500 hybridoma-containing wells were obtained, and $\sim 20$ wells gave positive binding results when initially screened with GST-MrNV. Hybridomas producing 4 MAbs specific to MrNV with high avidity to GSTMrNV but with different characteristics, classes, avidities and abilities for use in immunohistochemistry were selected and cloned to establish cell lines. All MAbs belonged to the IgG class (Table 1). Because MAbs MrNV-2 and MrNV-12 gave the best results in the various immunoassays described above, MAb MrNV-12 was used as a representative $\mathrm{MAb}$ for further experiments.

\section{Specificity of the monoclonal antibody}

In dot blotting, MAb MrNV-12 bound and gave an intense spot with Escherichia coli lysates containing GST-MrNV and with homogenates from MrNVinfected PL but did not bind to E. coli lysate containing GST or homogenate from uninfected PL (Fig. 3). Similar results were obtained using Western blotting

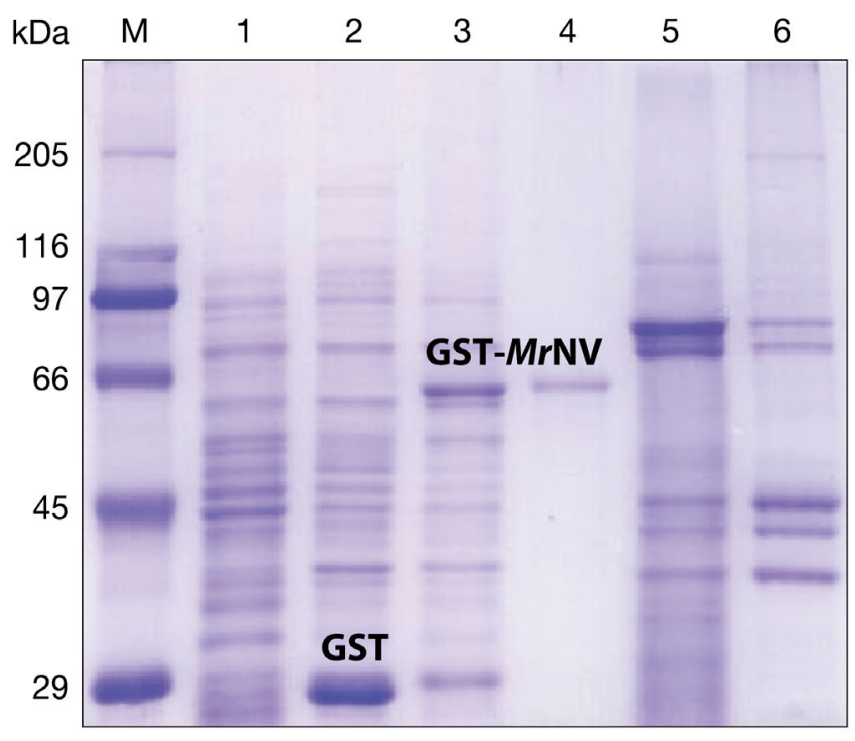

A

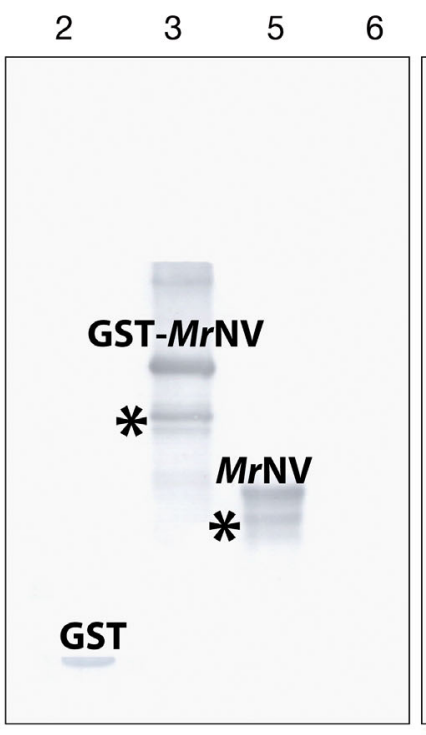

B

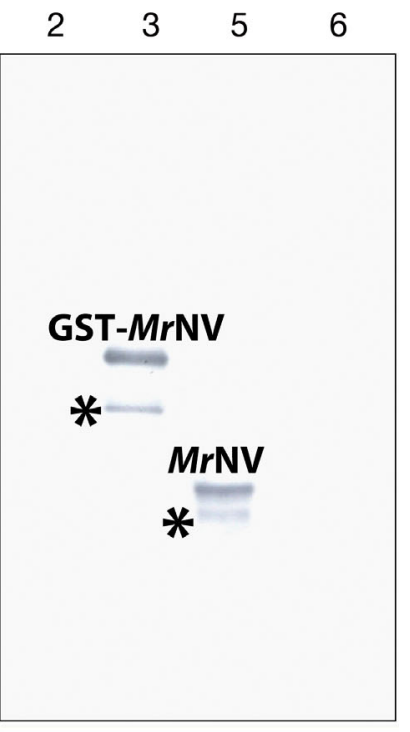

C

Fig. 2. SDS-PAGE and Western blotting analysis of antiserum and monoclonal antibody (MAb) specificity. (A) SDS-PAGE stained with Coomassie Brilliant Blue with the following lanes: (1) lysate of Escherichia coli BL21, (2) lysate of E. coli containing pGEX-6P-1-plasmid (GST = 26 kDa), (3) E. coli containing MrNV-pGEX-6P-1-plasmid (GST-MrNV = 64 kDa), (4) purified GST-MrNV capsid protein, (5) extract of homogenate from MrNV-infected postlarvae (PL) and (6) uninfected PL. (B) Nitrocellulose membrane transfer of gel in panel A probed with polyclonal antibody. (C) As in panel B but probed with MAb MrNV-12.

Lane M: standard marker proteins. *Putative degraded products of GST-MrNV or MrNV capsid protein 
Table 1. Monoclonal antibodies (MAbs) obtained from a mouse immunized with GST-MrNV. IHC: immunohistochemistry; -: no immunoreactivity; +: light immunoreactivity; +++ : strong immuno-reactivity

\begin{tabular}{|lcccc|}
\hline $\begin{array}{l}\text { MAb } \\
\text { (subclass) }\end{array}$ & $\begin{array}{c}\text { Sensitivity } \\
\left(\mathrm{fmol}^{-1}\right)\end{array}$ & $\begin{array}{c}\text { Western } \\
\text { blot }\end{array}$ & IHC & $\begin{array}{c}\text { Cross- } \\
\text { reactivity }\end{array}$ \\
\hline $\begin{array}{l}\text { MrNV-2 } \\
\text { (IgG2a) }\end{array}$ & 10 & +++ & +++ & None \\
$\begin{array}{l}\text { MrNV-12 } \\
\text { IgG2b) }\end{array}$ & 10 & +++ & +++ & None \\
$\begin{array}{l}\text { MrNV-15 } \\
\text { IgG2b) }\end{array}$ & 20 & +++ & + & None \\
$\begin{array}{l}\text { MrNV-24 } \\
\text { IgG1) }\end{array}$ & 20 & +++ & - & None \\
\hline
\end{tabular}

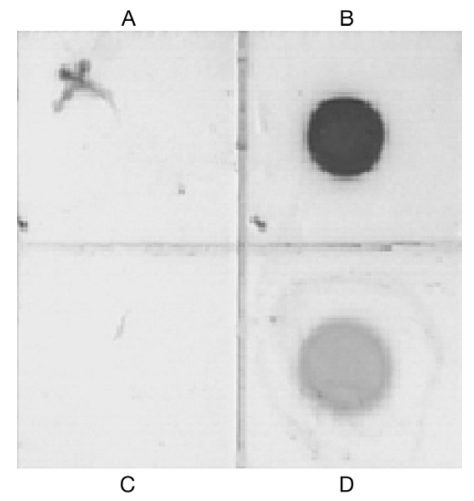

Fig. 3. Example of dot blot analysis using monoclonal antibody MrNV-12 with various extracts spotted $\left(1 \mu \operatorname{spot}^{-1}\right)$ onto a nitrocellulose membrane. (A) Lysate of Escherichia coli BL21 containing pGEX-6P-1 plasmid (GST), (B) lysate of E. coli containing MrNV-pGEX-6P-1-plasmid (GST-MrNV), (C) extract of homogenate from uninfected post larvae (PL) and (D) MrNV-infected PL

with MAb MrNV-12. The MAb bound to GSTMrNV (a single band at $43 \mathrm{kDa}$ ) in homogenate from MrNV-infected PL but did not bind to E. coli lysate containing GST or homogenate from uninfected PL (Fig. 2C). In the immunohistochemical analysis, 2 MAbs, MrNV-12 and MrNV-2, gave similar results, with strong immunoreactivities in infected muscles, gills, the heart, loose connective tissue, the nerve cord and the intertubular cells of the hepatopancreas of MrNV-infected shrimp (Fig. 4). None of the MAbs exhibited cross-reactivity to tissues from uninfected shrimp or shrimp infected with IMNV, WSSV, YHV, TSV, PmDNV, PstDNV or PemoNPV (data not shown). Of the other 2 MAbs, MrNV-15 gave a poor staining, and MrNV-24 did not give any staining for immunohistochemical localization of the viral infection (Table 1). Despite their lower avidity, the poor staining may have been the result of target epitope modification or epitope inaccessibility that can occur during the processes of preparing paraffin sections.

\section{Sensitivity testing with recombinant MrNV capsid protein}

To determine the sensitivity of the MrNV-specific MAbs, dot blotting against purified recombinant GST-MrNV protein was performed. The detection limit of the first 2 MAbs, MrNV-2 and MrNV-12, was approximately $600 \mathrm{ng} \mathrm{ml}^{-1}$, which is equivalent to

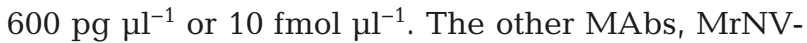
15 and MrNV-24, gave 2-fold less detection sensitivity (Table 1).

\section{Sensitivity comparison between MAbs and 1-step RT-PCR}

To compare the sensitivity of MrNV detection between dot blotting and 1-step RT-PCR, parallel, diluted homogenates from naturally infected PL were used for both assays. In the dot blot assay, the lowest limit of detection of each MAb, MrNV-2 and MrNV-12, was at a 1:320 dilution. However, when both MAbs were combined, the detection sensitivity limit increased to a 1:640 dilution (Fig. 5A-C). The other 2 MAbs, MrNV-15 and MrNV-24, gave similar results but with one dilution-step lower sensitivity (Fig. 5D-F). The improvement in sensitivity with combined pairs of MAbs demonstrated that they bound to non-overlapping epitopes of the antigen. However, a combination of all 4 MAbs did not yield any further significant increase in detection sensitivity (not shown).

In 1-step RT-PCR detection using the same PL homogenate, an amplicon band (1041 bp) was still observable at a dilution of $10^{-5}$ (Fig. 6). Therefore, in comparison with 1-step RT-PCR, the dot blot assay was approximately 200 -fold less sensitive.

\section{DISCUSSION}

Four MAbs specific to MrNV capsid protein were produced from a mouse immunized with a fusion GST-MrNV capsid protein. These MAbs could be used for detection of MrNV infection in PL using dot blotting, Western blotting and immunohistochemistry. MrNV infections have been localized using in situ hybridization only in striated muscle (Sri Widada 

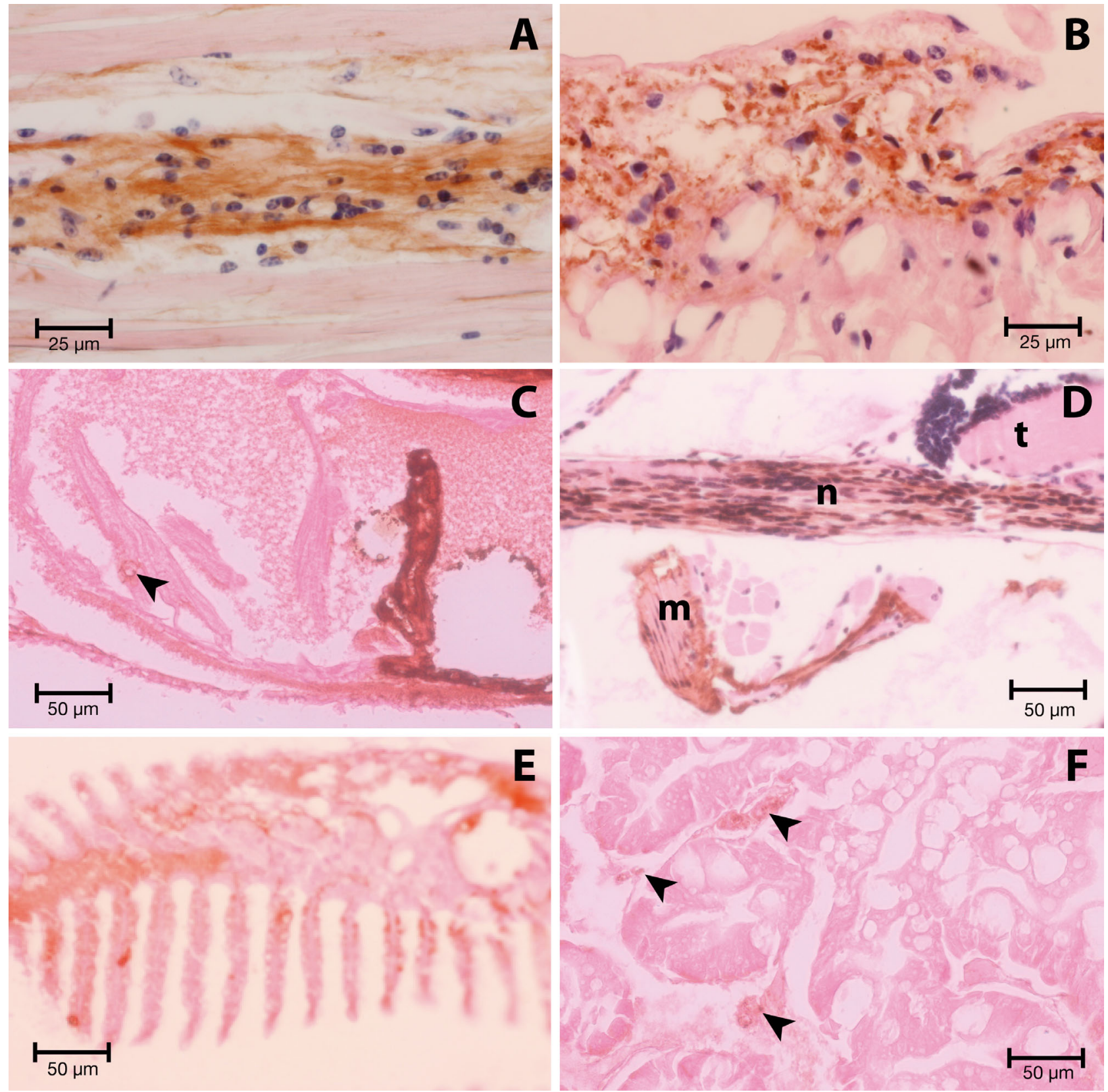

Fig. 4. Examples of immunohistochemical analysis using MAb MrNV-12. MrNV immunoreactivity was observed in adult Macrobrachium rosenbergii (A) muscle and (B) connective tissue and $M$. rosenbergii postlarvae (C) heart muscle, (D) nerve cord, (E) gills and (F) intertubular tissue of the hepatopancreas. Positive immunohistochemical reactions appeared as brown staining. Preparations were counterstained with hematoxylin and eosin $(A, B, D)$ or only eosin $(C, E, F)$. Arrowhead: light infection; $\mathrm{m}$ : striated muscle; $\mathrm{n}$ : nerve cord; t: thoracic ganglion

et al. 2003, Bonami \& Sri Widada 2011). Even though immunohistochemistry is simpler and easier for handling than in situ hybridization, and both MAbs and PAbs against MrNV capsid protein were produced for various types of ELISA (Romestand \& Bonami 2003, Qian et al. 2006, Sahul Hameed et al. 2011), immunolocalization of the MrNV in other infected tissues has not been reported previously using these 2 methods. In the present study, we used the MAbs to localize MrNV infection in additional tissues, including the nerve cord, loose connective tissue, intertubular tissue of the hepatopancreas, gills and the heart, resulting in an overall tissue distribution that was similar to those for infections of PvNV (Tang et 

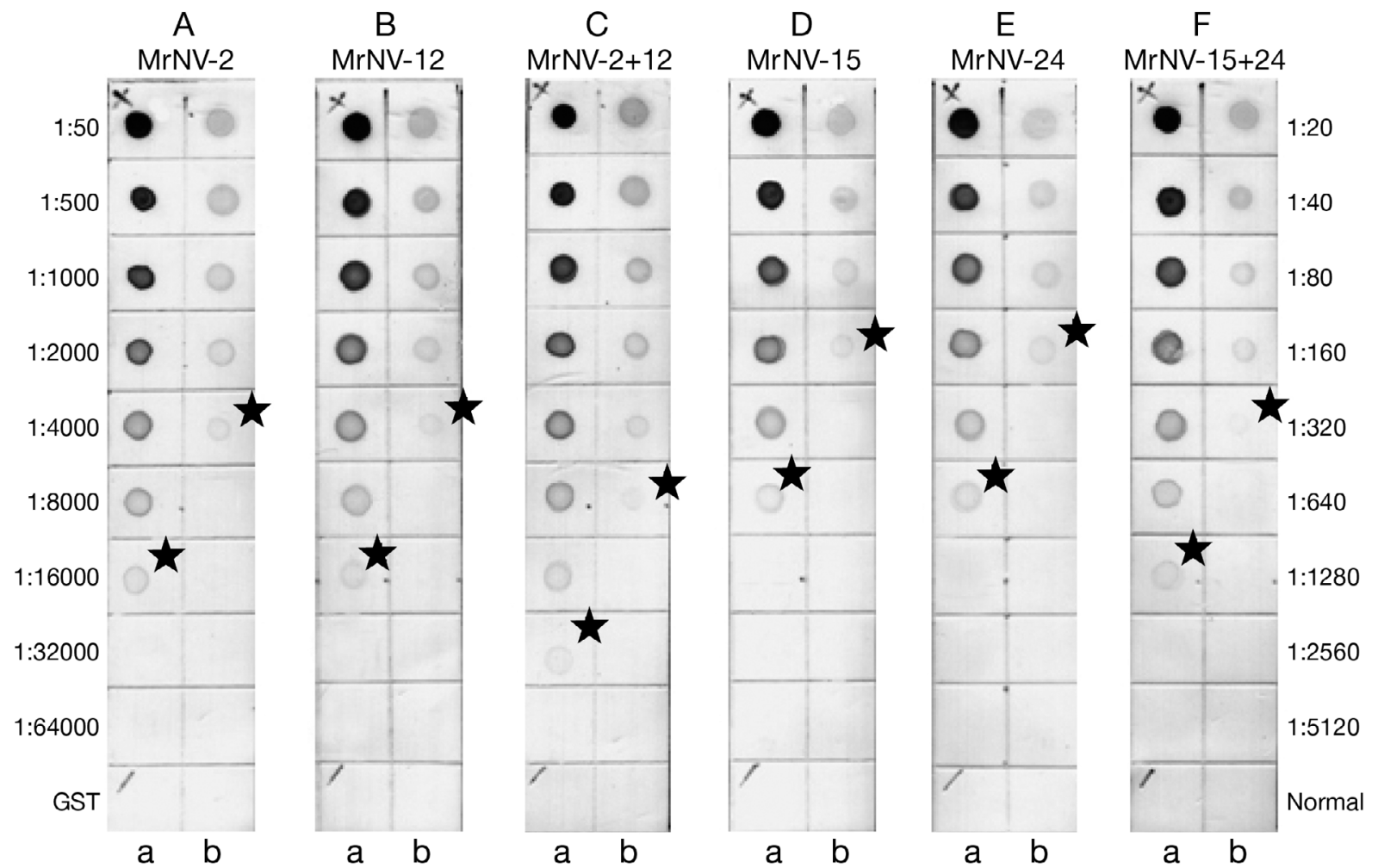

Fig. 5. Sensitivity of MrNV detection by dot blotting. Serially diluted lysate of Escherichia coli containing MrNV-pGEX-6P-1plasmid (column a) or homogenate extract from MrNV-infected postlarvae (PL) (column b) were spotted (1 $\mu$ l spot ${ }^{-1}$ ) onto each square of a nitrocellulose membrane. The last square of column a was spotted with lysate of E. coli containing pGEX-6P-1plasmid (GST) and column b with homogenate of uninfected PL (normal). Each nitrocellulose membrane was treated with a single $(\mathrm{A}, \mathrm{B}, \mathrm{D}, \mathrm{E})$ or a pair $(\mathrm{C}, \mathrm{F})$ of MAbs. (A) MrNV-2, (B) MrNV-12, (C) MrNV-2 + MrNV-12, (D) MrNV-15, (E) MrNV-24 and (F) MrNV-15 + MrNV-24. The numbers on the left side are dilution factors of the bacterial lysate containing GST-MrNV protein and the numbers on the right side are dilution factors of the PL homogenate from MrNV-infected PL ( $\star$ : lowest dilution giving a positive signal)

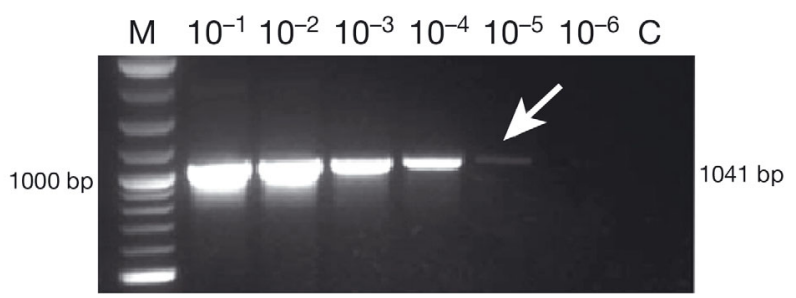

Fig. 6. RT-PCR analysis. The same samples of MrNVinfected PL used for dot blotting were diluted from $10^{-1}$ to $10^{-6}$ and processed for RT-PCR. The lowest limit of detection for the methods is indicated by an arrow. Lane M: DNA markers; Lane C: negative control using distilled water

al. 2007) and IMNV (Tang et al. 2005, Kunanopparat et al. 2011) in Penaeus vannamei, except that the MrNV infection in heart muscle was very rare (2 out of 15 samples) and the immunoreactivity occurred in the heart muscle cells rather than in the fixed hemocytes. The MrNV immunoreactivity in the heart muscle was specific because several nearby uninfected heart muscle fibers did not show MrNV immunoreac- tivity (Fig. 4C). In addition, the immunoreactivity in infected heart muscle fibers co-localized with the MAb specific to XSV (data not shown). Immunohistochemical detection could be observed even though the infection was located in very small focal areas or few cells (Fig. 4D,F). In some places, the immunoreactivity was observed around the cells or in the hemolymph. This phenomenon may have been a preparation artifact because the sample was collected in $70 \%$ ethanol before being fixed in Davidson's fixative. This may have caused the release of the virions from the infected cells into the surrounding tissues and hemolymph.

Purification of the recombinant GST-MrNV capsid protein using SDS-PAGE and electro-elution is a convenient method. This method could provide a sufficient amount of any recombinant protein, including intein-tagged or histidine-tagged recombinant proteins (Chaivisuthangkura et al. 2004, Kunanopparat et al. 2011) or natural capsid proteins of MrNV and XSV (Sahul Hameed et al. 2011). The 
purified recombinant proteins obtained from this method could be used successfully for the production of PAb and MAb that could bind to the native form of a natural antigen.

The avidity of 2 of our MAbs (MrNV-2 and MrNV12) were 2-fold higher than the other 2 (MrNV-15 and MrNV-24). The detection sensitivity of the first 2 was $10 \mathrm{fmol} \mathrm{\mu l}^{-1}$, as determined using dot blotting. In a sandwich ELISA using a PAb for MrNV, the lowest detection limit was $10 \mu \mathrm{g} \mathrm{ml}^{-1}\left(10 \mathrm{ng} \mathrm{ul}^{-1}\right)$ of viral preparation (Romestand \& Bonami 2003), and in a triple MAb sandwich-ELISA, the detection limit was $0.98 \mathrm{ng}$ for purified MrNV and $1.2 \mu \mathrm{g}$ total protein $\mathrm{ml}^{-1}$ for infected PL homogenate (Qian et al. 2006). The sensitivity among these $3 \mathrm{MrNV}$ assays could not be precisely compared due to differences in the purity and volume of antigen preparations used. However, the Western blot technique and indirect ELISA using PAbs against MrNV or XSV could be used to detect both viruses in experimentally infected PL at $24 \mathrm{~h}$ post infection; these results were confirmed by results from 1-step RT-PCR (Sahul Hameed et al. 2011).

Although the sensitivity of the antibody-based assay was poorer than that of PCR-based methods, the immunobased assays, including dot blotting, offer some advantages for farm management of viral infection risks, such as WSSV. Patil et al. (2008) compared the use of PCR tests and an MAb-based immunodot test for detecting WSSV in Penaeus monodon, and both were found to have value. For example, the lower detection of the immunodot test proved to be instructive regarding the likelihood of disease occurrences: all 6 farms at which WSSV was detected at various times post stocking had failed harvests. Conversely, the very high sensitivity of PCR can be instructive regarding the unlikelihood of disease occurrences: at 4 farms at which WSSV was only detected at various times following the use of a more sensitive 2-step PCR, shrimps were harvested successfully at $105 \mathrm{~d}$ post stocking (Patil et al. 2008). Similar PCR evidence of the long-term persistence of WSSV infections in the absence of disease, unless environmental stressors trigger elevated virus replication leading to the disease, has been obtained in other studies (Peng et al. 1998, Tsai et al. 1999). Therefore, the lower sensitivity of various immunoassays would provide shrimp farmers with a lower cost per test, while still being an effective diagnostic tool for monitoring viral infection, predicting impending disease and hence managing against production losses.
The sensitivity of the MAbs obtained in the present

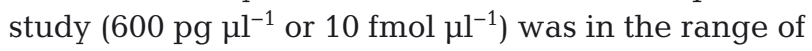
sensitivity limits reported for various other shrimp viruses, such as WSSV at 1.2 to $5 \mathrm{fmol}$ per spot for VP19 (Chaivisuthangkura et al. 2010a), 5 fmol per spot for VP28 (Chaivisuthangkura et al. 2004), 500 pg for VP28 (Anil et al. 2002), 400 pg for VP28 (Liu et al. 2002) and 625 pg per spot for VP28 (Makesh et al. 2006). For TSV, the detection limit per spot for MAbs against VP3 was 400 to 800 pg (Longyant et al. 2008) and against VP2 was 400 to 800 pg of VP2 (Chaivisuthangkura et al. 2010b), while that for the capsid protein of PstDNV was 300 pg (Sithigorngul et al. 2009). Because the MAbs targeted different epitopes on the MrNV capsid protein, they are expected to be useful for the development of an immunochromatographic strip test for simple and rapid detection of MrNV infection, as has been reported previously for WSSV and YHV (Sithigorngul et al. 2006, 2007, 2011).

In conclusion, MAbs specific to MrNV were generated from a mouse immunized with recombinant GST-MrNV capsid protein. The MAbs could be used to detect MrNV infection by Western blotting in a manner similar to that used for detection using 1-step RT-PCR in time-course infectivity studies. The MAbs were also used to expand the list of target tissues for MrNV infection. Because these MAbs target different capsid protein epitopes, they are promising for use in the development of an immunochromatographic strip test for simple and rapid detection of MrNV.

Acknowledgements. This work was supported by funding from the National Center for Genetic Engineering and Biotechnology (BIOTEC) Thailand to CENTEX Shrimp, Mahidol University. The authors are also indebted to farmers who provided MrNV infected shrimp samples.

\section{LITERATURE CITED}

Anil TM, Shankar KM, Mohan CV (2002) Monoclonal antibodies developed for sensitive detection and comparison of white spot syndrome virus isolates in India. Dis Aquat Org 51:67-75

Arcier JM, Herman F, Lightner DV, Redman RM, Mari J, Bonami JR (1999) A viral disease associated with mortalities in hatchery-reared postlarvae of the giant freshwater prawn Macrobrachium rosenbergii. Dis Aquat Org 38:177-181

Bonami JR, Sri Widada J (2011) Viral disease of the giant freshwater prawn, Macrobrachium rosenbergii: a review. J Invertebr Pathol 106:131-142

> Boonsanongchokying C, Sang-oum W, Sithigorngul P, Sriurairatana S, Flegel TW (2006) Production of monoclonal 
antibodies to polyhedrin of monodon baculovirus (MBV) from shrimp. Sci Asia 32:371-376

- Bradford MM (1976) A rapid and sensitive method for the quantification of microgram quantities of protein utilizing the principle of protein-dye binding. Anal Biochem 72:248-254

Chaivisuthangkura P, Tangkhabuanbutra J, Longyant S, Sithigorngul W, Rukpratanporn S, Menasveta P, Sithigorngul P (2004) Monoclonal antibodies against a truncated viral envelope protein (VP28) can detect white spot syndrome virus (WSSV) infections in shrimp. Sci Asia 30: 359-363

> Chaivisuthangkura P, Longyant S, Rukpratanporn S, Srisuk C, Sridulyakula P, Sithigorngul P (2010a) Enhanced white spot syndrome virus (WSSV) detection sensitivity using monoclonal antibody specific to heterologously expressed VP19 envelope protein. Aquaculture 299:15-20

Chaivisuthangkura P, Longyant S, Hajimasalaeh W, Sridulyakula P, Rukpratanporn S, Sithigorngul P (2010b) Improved sensitivity of Taura syndrome virus immunodetection with a monoclonal antibody against the recombinant VP2 capsid protein. J Virol Methods 163:433-439

Köhler G, Milstein C (1976) Derivation of specific antibody producing tissue culture and tumor lines by cell fusion. Eur J Immunol 6:511-519

Kunanopparat A, Chaivisuthangkura C, Senapin S, Longyant S, Rukpratanporn S, Flegel TW, Sithigorngul P (2011) Detection of infectious myonecrosis virus using monoclonal antibody specific to $\mathrm{N}$ and $\mathrm{C}$ fragments of the capsid protein expressed heterologously. J Virol Methods 171:141-148

> Laemmli UK (1970) Cleavage of structural proteins during the assembly of the head of bacteriophage T4. Nature 227:680-685

Liu W, Wang YT, Tian DS, Yin ZC, Kwang J (2002) Detection of white spot syndrome virus (WSSV) of shrimp by means of monoclonal antibodies (MAbs) specific to an envelope protein (28 kDa). Dis Aquat Org 49:11-18

Longyant S, Poyoi P, Chaivisuthangkura P, Tejankura T, Sithigorngul W, Sithigorngul P, Rukpratanporn S (2008) Specific monoclonal antibodies raised against Taura syndrome virus (TSV) capsid protein VP3 detect TSV in single and dual infections with white spot syndrome virus (WSSV). Dis Aquat Org 79:75-81

Makesh M, Koteeswaran A, Chandran NDJ, Manohar BM, Ramasamy V (2006) Development of monoclonal antibodies against VP28 of WSSV and its application to detect WSSV using immunocomb. Aquaculture 261:64-71

Mosmann TR, Bauman R, Williamson AR (1979) Mutations affecting immunoglobulin light chain secretion by myeloma cells. I. Functional analysis by cell fusion. Eur J Immunol 9:511-516

Owens L, La Fauce K, Juntunen K, Hayakijkosol O, Zeng C (2009) Macrobrachium rosenbergii nodavirus disease (white tail disease) in Australia. Dis Aquat Org 85: 175-180

Patil R, Palaksha KL, Anil TM, Guruchannabasavanna and others (2008) Evaluation of an immunodot test to manage white spot syndrome virus (WSSV) during cultivation of the giant tiger shrimp Penaeus monodon. Dis Aquat Org 79:157-161

Peng SE, Lo CF, Liu KF, Kou GH (1998) The transition from pre-patent to patent infection of white spot syndrome virus (WSSV) in Penaeus monodon triggered by pereiopod excision. Fish Pathol 33:395-400
Pillai D, Bonami JR, Sri Widada J (2006) Rapid detection of Macrobrachium rosenbergii nodavirus (MrNV) and extra small virus (XSV), the pathogenic agents of white tail disease of Macrobrachium rosenbergii (De Man), by loop-mediated isothermal amplification. J Fish Dis 29: 275-283

Puthawibool T, Senapin S, Kiatpathomchai W, Flegel TW (2010) Rapid and sensitive detection of Macrobrachium rosenbergii nodavirus in giant freshwater prawns by reverse transcription loop-mediated isothermal amplification combined with a lateral flow dipstick. Mol Cell Probes 24:244-249

Qian D, Shi Z, Zhang S, Cao Z and others (2003) Extra small virus-like particles (XSV) and nodavirus associated with whitish muscle disease in the giant freshwater prawn Macrobrachium rosenbergii. J Fish Dis 26:521-527

- Qian D, Liu W, Jianxiang W, Yu L (2006) Preparation of monoclonal antibody against Macrobrachium rosenbergii Nodavirus and application of TAS-ELISA for virus diagnosis in post-larvae hatcheries in east China during 2000-2004. Aquaculture 261:1144-1150

- Romestand B, Bonami JR (2003) A sandwich enzyme linked immunosorbent assay (S-ELISA) for detection of MrNV in the giant freshwater prawn, Macrobrachium rosenbergii (de Man). J Fish Dis 26:71-75

Rukpratanporn S, Sukhumsirichart W, Chaivisuthngkura P, Longyant S, Sithigorngul W, Menasveta P, Sithigorngul P (2005) Generation of monoclonal antibodies specific to hepatopancreatic parvovirus (HPV) from Penaeus monodon. Dis Aquat Org 65:85-89

Sahul Hameed AS, Yoganandhan K, Sri Widada JS, Bonami JR (2004) Studies on the occurrence of Macrobrachium rosenbergii nodavirus and extra small virus-like particles associated with white tail disease of $M$. rosenbergii in India by RT-PCR detection. Aquaculture 238:127-133

Sahul Hameed ASS, Ravi M, Farook MA, Taju G, Hernandez-Herrera RI, Bonami JR (2011) Screening the postlarva of Macrobrachium rosenbergii for early detection of Macrobrachium rosenbergii nodavirus (MrNV) and extra small virus (XSV) by RT-PCR and immunohistochemical techniques. Aquaculture 317:42-47

Senapin S, Molthathong S, Phiwsaiya K, Jaengsanong C, Chuchird N (2010) Application of high resolution melt (HRM) analysis for duplex detection of Macrobrachium rosenbergii nodavirus (MrNV) and extra small virus (XSV) in shrimp. Mol Cell Probes 24:291-297

Sithigorngul P, Chauychuwong P, Sithigorngul W, Longyant S, Chaivisuthangkura P, Menasveta P (2000) Development of a monoclonal antibody specific to yellow head virus (YHV) from Penaeus monodon. Dis Aquat Org 42: 27-34

Sithigorngul P, Rukpratanporn S, Longyant S, Chaivisuthangkura P, Sithigorngul W, Menasveta P (2002) Monoclonal antibodies specific to yellow-head virus (YHV) of Penaeus monodon. Dis Aquat Org 49:71-76

> Sithigorngul W, Rukpratanporn S, Pecharaburanin N, Longyant S, Chaivisuthangkura P, Sithigorngul P (2006) A simple and rapid immunochromatographic test strip for detection of white spot syndrome virus (WSSV) of shrimp. Dis Aquat Org 72:101-106

> Sithigorngul W, Rukpratanporn S, Sittidilokratna N, Pecharaburanin N, Longyant $S$, Chaivisuthangkura $P$, Sithigorngul P (2007) A convenient immunochromatographic test strip for rapid diagnosis of yellow head virus infection in shrimp. J Virol Methods 140:193-199 
Sithigorngul P, Hajimasalae W, Longyant S, Sridulyakul P, Rukpratanporn S, Chaivisuthangkura P (2009) Simple immunoblot and immunohistochemical detection of Penaeus stylirostris densovirus using monoclonal antibodies to viral capsid protein expressed heterologously. J Virol Methods 162:126-132

Sithigorngul P, Rukpratanporn S, Chaivisuthangkura $\mathrm{P}$, Sridulyakul P, Longyant S (2011) Simultaneous and rapid detection of white spot syndrome virus and yellow head virus infection in shrimp with a dual immunochromatographic strip test. J Virol Methods 173:85-91

Sri Widada J, Durand S, Cambournac I, Qian D and others (2003) Genome-based detection methods of Macrobrachium rosenbergii nodavirus, a pathogen of the giant freshwater prawn Macrobrachium rosenbergii: dot-blot, in situ hybridization and RT-PCR. J Fish Dis 26:583-590

Tang KFJ, Pantoja CR, Poulos BT, Redman RM, Lightner DV (2005) In situ hybridization demonstrates that Lithopenaeus vannamei, L. stylirostris and Penaeus monodon are susceptible to experimental infection with infectious myonecrosis virus (IMNV). Dis Aquat Org 63:261-265

Tang KFJ, Pantoja CR, Redman RM, Lightner DV (2007) Development of in situ hybridization and RT-PCR assay for the detection of a nodavirus (PvNV) that causes muscle necrosis in Penaeus vannamei. Dis Aquat Org 75: 183-190

Editorial responsibility: Grant Stentiford, Weymouth, UK
Tripathy S, Sahoo PK, Kumari J, Mishra BK, Sarangi N, Ayyappan S (2006) Multiplex RT PCR detection and sequence comparison of viruses MrNV and XSV associated with white tail disease Macrobrachium rosenbergii. Aquaculture 258:134-139

Tsai MF, Kou GH, Liu HC, Liu KF and others (1999) Longterm presence of white spot syndrome virus (WSSV) in a cultivated shrimp population without disease outbreaks. Dis Aquat Org 38:107-114

> Wang CS, Chang JS, Wen CM, Shih HH, Chen SN (2008) Macrobrachium rosenbergii nodavirus infection in $M$. rosenbergii (de Man) with white tail disease cultured in Taiwan. J Fish Dis 31:415-422

Yoganandhan K, Sri Widada J, Bonami JR, Sahul Hameed AS (2005) Simultaneous detection of Macrobrachium rosenbergii nodavirus and extra small virus by a single tube, one-step multiplex RT-PCR assay. J Fish Dis 28: 65-69

Yoganandhan K, Leartvibhas M, Sriwongpuk S, Limsuwan C (2006) White tail disease of the giant freshwater prawn Macrobrachium rosenbergii in Thailand. Dis Aquat Org 69:255-258

Zhang H, Wang J, Yuan J, Li L, Zhang J, Bonami JR, Shi Z (2006) Quantitative relationship of two viruses (MrNV and XSV) in white-tail disease of Macrobrachium rosenbergii. Dis Aquat Org 71:11-17

Submitted: June 24, 2011; Accepted: November 30, 2011 Proofs received from author(s): March 6, 2012 